\title{
EFEK EKSTRAK DAUN ALPUKAT (Persea americana Mill.) DALAM MENURUNKAN KADAR KOLESTEROL DARAH PADA MENCIT (Mus musculus)
}

\author{
Effect of Avocado (Persea americana Mill.) Leaves Extract in Lowering Cholesterol Blood Levels \\ in Mice (Mus musculus)
}

\author{
*Mufida, Nurdin Rahman dan Supriadi \\ Pendidikan Kimia/FKIP - Universitas Tadulako, Palu - Indonesia 94118 \\ Received 7 December 2017, Revised 5 January 2018, Accepted 6 February 2018
}

\begin{abstract}
This study aimed to determine the effective concentration of avocado leaves extract in lowering cholesterol blood levels in mice (Mus musculus). The animals test were 15 male mice and were induced with propylthiouracil and high-fat dietary food. Mice were divided randomly into 5 groups with different treatments. Treatments I, II and III were given avocado leaves extracts each with a concentration of 10, 20, and 40\%, respectively. Treatment $I V$ was given simvastatin suspension as a positive control, and treatment $V$ was given (Na-CMC) $1 \%$ as a negative control. Data were analyzed statistically with analysis of variance (ANOVA) test followed by Duncan test. The results showed that avocado leaves extract contained positively of alkaloids, flavonoids, saponins, tannins, and triterpenoid or steroids. Avocado leaves extract lowered cholesterol blood levels in mice with the most effective concentration was $10 \%(w / v)$.
\end{abstract}

Keywords: Avocado (Persea americana Mill.) leaves, cholesterol blood, flavonoids, saponin, tannins.

\section{Pendahuluan}

Kesehatan adalah modal yang nomor satu bagi kehidupan, karena dengan kondisi sehat manusia dapat beraktivitas dalam rangka menjalankan tugas bagi dirinya dan orang lain. Oleh sebab itulah perlu adanya langkah upaya menjaga kesehatan dapat dengan olah raga, pola makan yang teratur, dan istirahat yang cukup (Rahayu, 2005).

Indonesia kaya akan keanekaragaman hayati yang dapat dimanfaatkan dalam semua aspek kehidupan manusia. Obat tradisional adalah salah satu bentuk nyata pemanfaatan sumber daya hayati tersebut. Pemanfaatan keanekaragaman hayati dalam bentuk penggunaan obat-obat tradisional ini merupakan alternatif yang dinilai lebih ekonomis karena penggunaan obat-obatan yang diolah secara modern sulit dijangkau harganya oleh kebanyakan orang (Sangi, dkk., 2012).

Penggunaan suatu tanaman tertentu untuk tujuan pengobatan pada masyarakat berdasarkan pengalaman empiris ternyata pada tanaman tersebut juga mempunyai kandungan senyawa tertentu yang mempunyai aktivitas untuk pengobatan tersebut (Kusumawati, dkk., 2003).

Obat herbal pada umumnya lebih aman dibandingkan dengan obat sintesis karena obat herbal memiliki efek samping yang lebih sedikit dari pada sintesis. Pemulihan kesehatan dengan menggunakan tanaman obat tradisional tetap

\section{${ }^{*}$ Correspondence}

Mufida

Program Studi Pendidikan Kimia, Fakultas Keguruan dan Ilmu Pendidikan, Universitas Tadulako e-mail: mufida_alhadad91@yahoo.com Published by Universitas Tadulako 2018 berlanjut hingga saat ini, bahkan cenderung meningkat (Ong, 2013).

Kolesterol merupakan salah satu komponen susu yang terdapat lapisan tipis lemak susu. Sebagian besar lemak di dalam tubuh dan makanan terdapat dalam bentuk trigliserida yang dapat berbentuk lemak jenuh dan lemak tak jenuh (Hiperkolesterolemia) merupakan penyakit gangguan metabolisme kolesterol yang disebabkan oleh kadar kolesterol dalam darah melebihi batas normal (Murray, dkk., 2003).

Kolesterol sangat penting bagi manusia, dalam jumlah tertentu kolesterol dibutuhkan oleh tubuh untuk melakukan fungsi fisiologis yang vital. Namun dalam keadaan berlebih kolesterol menjadi berbahaya dan sumber timbulnya penyakit. Untuk mengatasinya dilakukan dengan menurunkan kadar kolesterol darah (Uneputty, dkk., 2013).

Kolesterol sendiri tidak larut dalam darah, untuk itu perlu berikatan dengan pengangkutnya yaitu high density lipoprotein (HDL). Kolesterol yang normal harus di bawah $200 \mathrm{mg} / \mathrm{dL}$, apabila di atas $240 \mathrm{mg} / \mathrm{dL}$, maka berisiko tinggi terkena serangan jantung atau stroke (Faisal, 1993).

Hiperkolesterolemia adalah gangguan metabolisme lipoprotein ditandai dengan serum yang tinggi densitas rendah lipoprotein dan kolesterol darah. Ini adalah faktor risiko utama dalam pengembangan dan perkembangan aterosklerosis yang menyebabkan penyakit kardiovaskular (Rerkasem, dkk., 2008).

Penurunan kadar kolesterol darah adalah salah satu langkah perawatan kesehatan yang mencegah dari penyakit jantung (Freeman \& Junge, 2005).

Kadar kolesterol tinggi dapat dilakukan dengan cara mengkonsumsi obat-obatan hipolipidemia. Obat-obatan hipolipidemia adalah obat yang digunakan untuk menurunkan kadar lipid plasma. 
Namun, harga obat-obatan hipolipidemia yang mahal, menyebabkan tidak semua orang dapat menjangkaunya. Pencarian terhadap obat-obatan hipolipidemia terutama yang berasal dari alam sangat giat dilakukan. Obat-obatan dari alam ini selain murah dan mudah didapat, juga memiliki efek samping yang kecil sehingga relatif aman jika dibandingkan obat-obatan sintesis. Tumbuhan merupakan sumber senyawa kimia, baik yang sudah diketahui maupun yang belum diketahui jenisnya, dimana banyak diantaranya berpotensi sebagai bahan dasar obat-obatan (Dachriyanus, dkk., 2007).

Alpukat (Persea americana Mill.) adalah buah yang banyak dikonsumsi di banyak negara dalam manfaat gizi dan obat (Al-Dosari, 2011). Daun alpukat memiliki kandungan senyawa kimia yang diantaranya adalah flavonoid sendiri berperan sebagai antioksidan yang menangkal radikal bebas. Oleh karena itu, konsumsi daun alpukat efektif mencegah gejala dan penyakit kanker. Senyawa ini dipercaya mampu melindungi tubuh dari serangan berbagai jenis penyakit yakni dengan mencegah proses peroksidasi lemak. Khasiat biji alpukat selain buah dan daunnya ternyata juga bermanfaat untuk beberapa penyakit, diantaranya adalah dapat mengobati sakit gigi (Katja, dkk., 2009).

Daun alpukat mengandung alkaloid, flavonoid, saponin, tanin, dan triterpenoid dimana zat bioaktif tersebut diketahui dapat berperan aktif dalam menurunkan kadar kolesterol (Yuniarti, 2008).

Alkaloid merupakan golongan terbesar dari senyawa metabolit sekunder pada tumbuhan. Umumnya alkaloid merupakan senyawa bersifat basa yang mengandung satu atau lebih atom nitrogen sebagai bagian dari sistem siklik. Alkaloid seringkali bersifat racun bagi manusia, tetapi beberapa alkaloid memiliki aktivitas faramakologis dan digunakan secara luas dalam bidang kesehatan (Harborne, 1987).

Flavonoid merupakan senyawa metabolit sekunder yang terdapat pada tanaman hijau, kecuali alga. Flavonoid yang lazim ditemukan pada tumbuhan tingkat tinggi (Angiospermae) adalah flavon dan flavonol dengan C- dan O-glikosida, isoflavon C- dan O-glikosida, flavanon C dan Oglikosida, khalkon dengan C- dan O-glikosida, dan dihidrokhalkon, proantosianidin dan antosianin, auron O-glikosida, dan dihidroflavonol Oglikosida. Golongan flavon, flavonol, flavanon, isoflavon, dan khalkon juga sering ditemukan dalam bentuk aglikonnya (Rohyami, 2008).

Flavonoid memiliki kerangka dasar karbon yang terdiri dari 15 atom karbon dan digambarkan sebagai deretan senyawa C6-C3-C6. Artinya, kerangka karbonnya terdiri atas dua gugus C6 yang dihubungkan dengan rantai alifatik tiga karbon. Susunan ini dapat menghasilkan tiga jenis struktur, yaitu 1,3-diarilpropan atau neoflavonoid, 1,2diarilpropan atau isoflavon, dan 1,1-dirilpropan atau neoflavonoid (Cowan, 1999).
Saponin merupakan glikosida triterpen dan sterol yang terdeteksi pada lebih dari 90 jenis tumbuhan. Saponin merupakan senyawa yang bersifat seperti sabun yang dapat dideteksi berdasarkan kemampuannya membentuk busa dan saponin memberikan rasa pahit pada bahan pangan nabati (Sirait, 2007).

Tanin merupakan senyawa polifenol yang memiliki berat molekul cukup tinggi (lebih dari 1000) dan dapat membentuk kompleks dengan protein. Tanin terdapat luas dalam tumbuhan berpembuluh, dalam angoispermae terdapat khusus dalam jaringan kayu (Harborne, 1987).

Triterpenoid adalah senyawa dengan kerangka karbon yang disusun dari enam unit isoprena dan secara biosintesis diturunkan dari hidrokarbon C30 asiklik yaitu skualen. Senyawa ini berstruktur siklik yang rumit, kebanyakan berupa alkohol, aldehida, atau asam karboksilat. Steroid merupakan golongan dari senyawa triterpenoid (Harborne, 1987).

Tanaman dikenal banyak mengandung senyawa-senyawa kimia khususnya senyawa metabolit sekunder. Salah satu senyawa metabolit sekunder yang terkandung di dalam tanaman adalah senyawa triterpenoid. Senyawa tersebut dapat dijumpai pada bagian akar, batang, daun, buah maupun biji tanaman (Widiyati, 2006).

Tulisan ini dimaksudkan untuk mengetahui senyawa fitokimia yang terdapat pada ekstrak daun alpukat dan menentukan konsentrasi ekstrak daun alpukat yang efektif untuk menurunkan kadar kolesterol darah pada mencit. Manfaat dari penelitian ini adalah diharapkan dapat memberikan informasi yang mudah diaplikasikan pada masyarakat untuk memanfaatkan tanaman alpukat khususnya, daun alpukat sebagai salah satu obat tradisional yang dapat digunakan sebagai antikolesterol.

\section{Metode}

\section{Alat dan Bahan}

Alat yang digunakan pada penelitian ini meliputi gelas ukur, gelas kimia, labu ukur, Erlenmeyer, Nesco multicheck, alat sonde, botol semprot, spoit oral, corong, lumpang dan alu, hot plate, neraca analitik adam, kandang hewan uji, timbangan hewan, batang pengaduk, spatula, blender, penangas air, ayakan 50 mesh, aluminium foil, wadah, dan kain flanel.

Bahan yang digunakan dalam penelitian ini meliputi $\mathrm{HCl}$ pekat (Smart Lab-Indonesia), $\mathrm{HCl} 2$ $\mathrm{N}$ (Smart Lab-Indonesia), $\mathrm{FeCl}_{3} \quad 1 \% \quad$ (Ajax chemicals UNILAB), Alkohol $70 \%, \mathrm{H}_{2} \mathrm{SO}_{4}$ pekat (Merck KGaA), $\mathrm{HgCl}_{2}$ (Merck), KI (Merck), Etanol $\left(\mathrm{C}_{2} \mathrm{H}_{5} \mathrm{OH}\right)$ (Merck), Pereaksi mayer (Merck), aquades, sampel daun alpukat, kuning telur ayam, minyak goreng bekas, pipet tetes, hewan uji mencit jantan putih, Propiltiourasil, Na-CMC (NatriumCarboxymethyle (ellulose), dan simvastatin. 


\section{Prosedur Kerja}

\section{Preparasi sampel}

Daun alpukat diambil pada bagian daun yang tidak terlalu tua (daun kelima dari pucuk). Daun alpukat dibersihkan terlebih dahulu dengan air kemudian dikeringkan. Ditimbang sebanyak \pm 300 gram daun alpukat dan dikeringkan sampai kering kemudian diletakkan ditempat terbuka dengan sirkulasi udara yang baik dan tidak terkena sinar matahari langsung dengan cara menutup wadah menggunakan kain flanel hitam. Daun alpukat yang sudah kering selanjutnya dihancurkan (menggunakan blender) sampai halus. Serbuk daun alpukat yang terbentuk diayak dengan menggunakan ayakan 50 mesh (Putri, 2013).

\section{Uji senyawa fitokimia metabolit sekunder dari} ekstrak daun alpukat (Persea americana Mill.)

\section{Uji alkaloid}

0,5 gram sampel ditimbang selanjutnya ditambahkan $5 \mathrm{~mL}$ etanol kemudian disaring. Filtrat ditambahkan dengan reagen Meyer setetes demi setetes. Apabila menghasilkan endapan yang berwarna putih maka hasilnya bereaksi positif.

\section{Uji flavonoid}

0,5 gram sampel ditimbang selanjutnya ditambahkan $5 \mathrm{~mL}$ etanol kemudian disaring. Filtrat ditambahkan dengan 0,1 gram logam $\mathrm{Mg}$ dan 5 tetes $\mathrm{HCl}$. Apabila menghasilkan berwarna kuning jingga maka bereaksi positif.

\section{Uji saponin}

0,5 gram sampel ditimbang selanjutnya ditambahkan $10 \mathrm{~mL}$ aquades panas dan didinginkan kemudian disaring. Filtrat dikocok sampai muncul buih, kemudian didiamkan selama 2 menit. Ditambahkan dengan 2 tetes $\mathrm{HCl} 2 \mathrm{~N}$ dan dikocok lagi sampai terbentuk buih yang mantap selama 30 menit.

\section{Uji tanin}

0,5 gram sampel ditimbang selanjutnya ditambahkan $5 \mathrm{~mL}$ etanol kemudian disaring Filtrat yang terbentuk ditetesi $\mathrm{FeCl}_{3} 1 \%$, apabila terbentuk warna biru tua maka bereaksi positif.

\section{Uji steroid dan triterpenoid}

0,5 gram sampel ditimbang selanjutnya ditambahkan dengan $5 \mathrm{~mL}$ larutan etanol kemudian disaring. Filtrat ditambahkan dengan 3 tetes $\mathrm{HCl}$ pekat serta 2 tetes $\mathrm{H}_{2} \mathrm{SO}_{4}$ pekat. Jika positif terpenoid maka akan terbentuk warna merah atau ungu dan positif steroid jika terbentuk warna hijau (Dharmayudha \& Anthara, 2013).

\section{Pembuatan propiltiourasil $0.01 \%$}

Propiltiourasil diberikan pada mencit melalui air minumnya dengan konsentrasi propiltiourasil sebesar $0.01 \%$, artinya dalam 1 Liter air terlarut $100 \mathrm{mg}$ propiltiourasil untuk mempermudah keadaan hiperkolesterolemia (Arief, dkk., 2012).

\section{Pembuatan makanan diet lemak}

Makanan diet lemak tinggi terdiri dari campuran kuning telur, minyak goreng bekas, dan makanan standar (jagung), untuk diberikan kepada mencit sebagai pakan. Cara pembuatannya adalah menggoreng kuning telur ayam sampai matang kemudian memotong kuning telur tersebut menggunakan pisau dan diberikan pada mencit tersebut.

\section{Pembuatan larutan dan suspensi}

\section{Pembuatan koloid Na-CMC $1 \%$ b/v}

1 gram $\mathrm{Na}-\mathrm{CMC}$ dilarutkan sedikit demi sedikit ke dalam $50 \mathrm{~mL}$ aquades panas sambil diaduk hingga terbentuk koloid. Volume dicukupkan hingga $100 \mathrm{~mL}$ dengan aquades.

\section{Pembuatan larutan simvastatin}

1 tablet simvastatin $10 \mathrm{mg}$ digerus menggunakan lumpang dan alu. Bubuk simvastatin $0,052 \mathrm{mg} / 20$ gram berat badan mencit dengan dilarutkan ke dalam $0,1 \mathrm{~mL}$ aquades, kemudian ditambahkan dengan koloid $\mathrm{Na}-\mathrm{CMC}$ $1 \% \mathrm{~b} / \mathrm{v}$ sedikit demi sedikit digerus hingga homogen. Dimasukkan dalam labu ukur $100 \mathrm{~mL}$ kemudian dicukupkan hingga volumenya $100 \mathrm{~mL}$ dengan koloid $\mathrm{Na}-\mathrm{CMC} 1 \% \mathrm{~b} / \mathrm{v}$.

\section{Pembuatan ekstrak daun alpukat dalam berbagai konsentrasi}

Ekstrak daun alpukat dibuat dengan menggunakan metode dekok. Serbuk daun alpukat yang telah kering ditimbang sebanyak 10 gram. Kemudian dimasukkan ke dalam gelas kimia dan ditambahkan dengan aquades sebanyak $100 \mathrm{~mL}$. Kemudian dipanaskan pada suhu $90^{\circ} \mathrm{C}$ selama 15 sampai 20 menit. Setelah itu campuran didiamkan dan kemudian disaring menggunakan kain flanel dan jika volume kurang dari $100 \mathrm{~mL}$, maka ditambahkan dengan air hangat melalui residu saringan hingga volumenya mencapai $100 \mathrm{~mL}$. Ekstrak daun alpukat 20\% dan $40 \%$ dibuat dengan cara yang sama menggunakan 20 gram dan 40 gram ekstrak daun alpukat (Dharmayudha \& Anthara, 2013).

\section{Pemilihan dan penyiapan hewan uji}

Hewan uji yang digunakan adalah mencit (Mus musculus) jantan berbadan sehat, berumur 2-3 bulan dengan bobot berat badan yang bervariasi antara 20-30 gram. Mencit yang digunakan sebanyak 15 ekor dan dibagi dalam 5 kelompok perlakuan. Penggunaan mencit sebagai hewan uji didasari alasan bahwa mencit jantan mempunyai kemiripan dengan manusia dalam hal fisiologis, metabolisme, dan lazim digunakan dalam penelitian mengenai kadar kolesterol karena pengambilan serum darahnya relatif mudah, mencit jantan digunakan karena sedikit terpengaruh oleh perubahan hormonal (Putri, 2013). 


\section{Perlakuan terhadap hewan uji}

Mencit diadaptasi (aklimasi) sebelum diberikan perlakuan selama 2 minggu agar dapat menyesuaikan diri dengan lingkungan. Selama waktu tersebut, seluruh mencit diberi pakan standar dan air minum, pada percobaan awal semua hewan mencit ditimbang berat badannya untuk mendapatkan data awal tentang berat badan mencit dan ditentukan kadar kolesterol awalnya setelah dipuasakan selama 18 jam. Memberikan ekstrak daun alpukat pada mencit secara oral menggunakan alat sonde selama 7 hari, kemudian dikelompokkan secara acak. Masing-masing kelompok terdiri atas:

Kelompok yang diberikan diet kolesterol tinggi dan minuman yang mengandung propiltiourasi $0,01 \%$ + simvastatin selama 7 hari (kelompok kontrol positif).

Kelompok yang diberikan diet kolesterol tinggi dan minuman yang mengandung propiltiourasil $0,01 \%$ selama 7 hari (kelompok kontrol negatif).

Kelompok yang diberikan diet kolesterol tinggi, $\mathrm{Na} \mathrm{CMC}$, dan minuman yang mengandung propiltiourasil $0,01 \%$ disamping itu diberikan juga bahan uji selama 7 hari (kelompok uji).

Setelah perlakuan pada mencit, pengukuran kadar kolesterol darah akhir dilakukan pada hari terakhir untuk setiap mencit pada masing-masing kelompok dengan memotong ujung ekor mencit menggunakan gunting untuk pengambilan serum darah. Pengukuran serum darah dilakukan dengan menggunakan alat Nesco multicheck. Pengujian mencit ini dibagi atas perlakuan (bahan uji yang terdiri dari 3 konsentrasi dan bahan pembanding positif dan negatif), masing-masing perlakuan terdiri dari 3 ekor mencit jantan dimana ketiga mencit tersebut diletakkan terpisah untuk setiap perlakuan. Adapun perlakuan yang diberikan sebagai berikut:

Kelompok I Pakan + minuman yang (P1) : $\quad$ mengandung Propiltiourasil 0,01\% + Ekstrak daun alpukat $10 \%+\mathrm{Na}-$ CMC $1 \%$.

Kelompok II Pakan + minuman yang (P2) : $\quad$ mengandung Propiltiourasil 0,01\% + Ekstrak daun alpukat $20 \%+\mathrm{Na}-$ CMC $1 \%$.

Kelompok III Pakan + minuman yang (P3) : $\quad$ mengandung Propiltiourasil 0,01\% + Ekstrak daun alpukat $40 \%+\mathrm{Na}-$ CMC $1 \%$.

Kelompok IV Pakan + minuman yang (P4) : $\quad$ mengandung Propiltourasil $0,01 \%$ + Simvastatin + Na-CMC $1 \%$ (Sebagai kontrol positif).

Kelompok V Pakan + minuman yang (P5) : $\quad$ mengandung Propiltiourasil 0,01\% $+\mathrm{Na}-\mathrm{CMC} 1 \%$ (Sebagai kontrol negatif).

Setelah diberikan perlakuan semua mencit diistirahatkan ke dalam kandangnya masingmasing dan diberikan makanan dan minuman.

\section{Penentuan kadar kolesterol darah}

Sebelum digunakan, Nesco multicheck dihidupkan dan strip kolesterol dimasukkan ke dalam Nesco multicheck. Darah diambil melalui ujung ekor mencit kemudian diteteskan pada strip Nesco multicheck. Dalam waktu 150 detik kadar kolesterol darah akan terukur secara otomatis dan hasilnya dapat dibaca pada monitor Nesco multicheck (Rinaldi, 2011).

\section{Pengumpulan dan analisa data}

Data hasil pengukuran kadar kolesterol darah mencit yang diperoleh dirata-ratakan untuk tiap perlakuan. Selanjutnya dianalisis dan dievaluasi menggunakan program statistik dengan Analisis Varians (Anova) dan taraf kepercayaan 95\% (UjiF). Uji ini digunakan untuk mengetahui apakah antar perlakuan yang diberikan terdapat perbedaan yang signifikan atau tidak. Jika terdapat perbedaan yang signifikan maka pengujian dilanjutkan dengan uji Duncan. Uji Duncan adalah uji lanjutan yang bertujuan untuk mengetahui pada kadar berapa ekstrak daun alpukat paling signifikan dalam menurunkan kadar kolesterol darah mencit jantan.

\section{Hasil dan Pembahasan}

\section{Uji senyawa fitokimia metabolit sekunder dari} ekstrak daun alpukat (Persea americana Mill.)

Berdasarkan hasil pengamatan pada uji pendahuluan terhadap adanya senyawa alkaloid, flavonoid, saponin, tanin, triterpenoid dan steroid maka diperoleh data Tabel 1.

Tabel 1. Hasil uji senyawa fitokimia ekstrak daun apukat

\begin{tabular}{|c|c|c|c|}
\hline No & Perlakuan & Hasil Pengamatan & Hasil \\
\hline 1 & Uji Alkaloid & $\begin{array}{l}\text { Terbentuk } \\
\text { endapan putih dan } \\
\text { menghasilkan } \\
\text { warna orange }\end{array}$ & Positif \\
\hline 2 & Uji Flavonoid & $\begin{array}{l}\text { Menghasilkan } \\
\text { larutan berwarna } \\
\text { kuning jingga dan } \\
\text { terdapat sedikit } \\
\text { endapan berwarna } \\
\text { kuning }\end{array}$ & Positif \\
\hline 3 & Uji Saponin & $\begin{array}{l}\text { Tidak terbentuk } \\
\text { buih yang mantap }\end{array}$ & Negatif \\
\hline 4 & Uji Tanin & $\begin{array}{l}\text { Menghasilkan } \\
\text { larutan berwarna } \\
\text { biru tua }\end{array}$ & Positif \\
\hline 5 & $\begin{array}{l}\text { Uji Triterpenoid } \\
\text { dan Steroid }\end{array}$ & $\begin{array}{l}\text { Terbentuk warna } \\
\text { merah atau ungu } \\
\text { dan uji positif } \\
\text { steroid terbentuk } \\
\text { warna hijau }\end{array}$ & Positif \\
\hline
\end{tabular}

Dari data Tabel 1 dapat dilihat bahwa pada uji metabolit sekunder dari ekstrak daun alpukat mengandung senyawa aktif berupa senyawa alkaloid, flavonoid, saponin, tanin, triterpenoid dan steoid. Uji ini bertujuan untuk mengetahui adanya senyawa metabolit sekunder yang 
diharapkan agar dapat berperan penting sebagai hiperkolesterol dan antikolesterol.

Selanjutnya kandungan senyawa kimia daun alpukat yang dapat menurunkan kolesterol yaitu senyawa kimia flavonoid. Peranan dan fungsi flavonoid ini terhadap penurunan kolesterol adalah dapat berfungsi dalam menurunkan kadar kolesterol darah. Hal tersebut disebabkan senyawa flavonoid dapat mencegah oksidasi low densiry lippoprotein (LDL) sehingga pembentukkan sel busa dan kerusakan lipid tidak terjadi (Astawan, 2008).

Daun alpukat dapat dijadikan sebagai obat penurun kadar kolesterol darah dan dilakukan analisis kualitatif senyawa fitokimia pada ekstrak daun alpukat. Antioksidan dapat berperan dalam penurunan kadar kolesterol dan membantu memecah terjadinya proses oksidasi lemak yang apabila terjadi oksidasi lemak, maka kolesterol menjadi mudah melewati dinding arteri dan menyumbatnya. Pengujian metabolit sekunder yang diuji dalam ekstrak daun alpukat yaitu senyawa alkaloid, flavanoid, saponin, tanin, triterpenoid dan steroid (Povey, dkk., 1994).

Flavonoid dapat mengurangi kadar kolesterol darah pada mencit yang mengalami hiperlipidemia dan mengurangi oksidasi kolesterol low densiry lippoprotein (LDL) yang memiliki peranan penting dalam proses aterogenesis. Flavonoid mengurangi sintesis kolesterol dengan cara menghambat aktivitas enzim acyl-CoA cholesterol acyl transferase (ACAT) pada sel HepG2 yang berperan dalam penurunan esterifikasi kolesterol pada usus dan hati, serta menghambat aktivitas enzim 3-hidroksi3-metil-glutaril-CoA yang menyebabkan penghambatan sintesis kolesterol (Metwally, dkk., 2009).

\section{Pengaruh Konsentrasi Ekstrak Daun Alpukat (Persea americana Mill.) terhadap Penurunan Kadar Kolesterol Darah.}

Hasil rerata pengukuran kadar kolesterol darah awal, akhir, dan penurunan kolesterol dalam darah setelah pemberian ekstrak daun alpukat pada Tabel 2.

Tabel 2. Rerata pengukuran kadar kolesterol awal, akhir, dan penurunan

\begin{tabular}{|c|c|c|c|}
\hline \multirow[b]{2}{*}{ Perlakuan } & \multicolumn{3}{|c|}{ Kadar Kolesterol Darah Mencit (mg/dl) } \\
\hline & $\begin{array}{c}\text { Kolesterol } \\
\text { Darah Awal }\end{array}$ & $\begin{array}{c}\text { Kolesterol } \\
\text { Darah } \\
\text { Akhir }\end{array}$ & $\begin{array}{c}\text { Penurunan } \\
\text { Kolesterol } \\
\text { Darah }\end{array}$ \\
\hline$(10 \%) \mathrm{P} 1$ & 160,33 & 113,33 & $+47,00$ \\
\hline$(20 \%)$ P2 & 160,67 & 119,33 & $+41,33$ \\
\hline (40\%) P3 & 162,33 & 135,00 & $+27,33$ \\
\hline (+) P4 & 160,33 & 129,33 & $+31,00$ \\
\hline$(-) \quad$ P5 & 160,00 & 191,33 & $-31,33$ \\
\hline
\end{tabular}

Angka dengan huruf yang sama dalam kelompok yang sama tidak berbeda nyata pada $\alpha=$ 0,05

Hasil pada Tabel 2 menunjukkan bahwa rerata kolesterol awal mencit berkisar dari 160,00-162,33 $\mathrm{mg} / \mathrm{dL}$, dan kolesterol akhir berkisar dari 113,33$191,33 \mathrm{mg} / \mathrm{dL}$. Mengetahui seberapa besar penurunan kadar kolesterol darah pada mencit maka dilakukan perhitungan selisih antara kadar kolesterol darah awal dengan kolesterol darah akhir.

Hasil homogenitas kadar kolesterol darah mencit setelah induksi propiltiourasil menunjukkan tidak ada perbedaan yang signifikan antar kelompok perlakuan $(\mathrm{p}<0.05)$ atau nilai signifikan $0,02<0.05$. Dengan demikan, semua kelompok perlakuan layak dibandingkan karena tidak ada perbedaan yang signifikan. Untuk mengetahui penurunan kadar kolesterol pada mencit dapat dihitung rata ratanya seperti yang terlihat pada Tabel 2. Adapun grafik yang memperlihatkan penurunan kolesterol darah pada mencit terlihat pada Gambar 1.

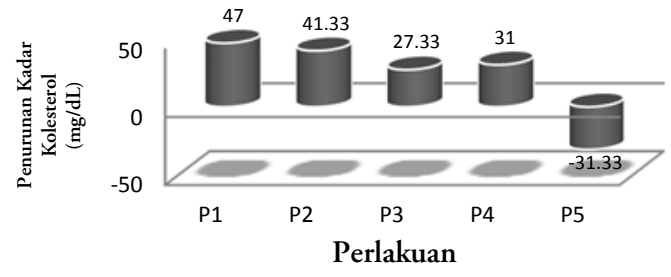

Gambar 1. Grafik penurunan kolestrol pada mencit

Gambar 1 menunjukkan bahwa rata-rata penurunan kolesterol darah tersebut berbeda antara beberapa perlakuan. Penurunan kadar kolesterol tertinggi terdapat pada $\mathrm{P} 1$ perubahan kadar kolestrol dalam darah tersebut mempunyai pengaruh positif bagi tubuh karena kadar kolesterol yang berlebihan akan menyebabkan ateroklerosis yang akan berdampak pada penyakit jantung koroner. Sedangkan pada perlakuan (P5) pada kontrol negatif tidak terjadi penurunan kadar kolesterol darah karena pada perlakuan lima tidak diberikan obat simvastatin dan ekstrak daun alpukat, sehingga penurunan kadar kolesterol pada perlakuan lima tidak terjadi. Dimana pada ekstrak daun alpukat dapat menurunkan kadar kolesterol karena adanya senyawa aktif yang terkandung didalam daun alpukat yaitu flavanoid, alkaloid, saponin, tanin, triterpenoid dan steroid yang berperan untuk menurunkan kadar kolesterol.

Penentuan adanya perbedaan yang signifikan antar kelima perlakuan dapat diketahui dengan melakukan uji statistik menggunakan analisis varians (Anova), terlihat pada Tabel 3.

Tabel 3. Hasil uji Anova untuk penurunan kolesterol

\begin{tabular}{|c|c|c|c|c|c|}
\hline & $\begin{array}{l}\text { Sum of } \\
\text { Squares }\end{array}$ & $\mathrm{df}$ & $\begin{array}{l}\text { Mean } \\
\text { Square }\end{array}$ & $\mathrm{F}$ & Sig. \\
\hline Between & & & \multirow{4}{*}{$\begin{array}{c}2960.233 \\
298.800\end{array}$} & \multirow{4}{*}{9.907} & \multirow{4}{*}{.002} \\
\hline Groups & 11840.933 & 4 & & & \\
\hline Within & 2988.000 & 10 & & & \\
\hline $\begin{array}{c}\text { Groups } \\
\text { Total }\end{array}$ & 14828.933 & 14 & & & \\
\hline
\end{tabular}


Setelah uji anova tersebut, kemudian dilanjutkan dengan uji Duncan. Hasil uji Duncan terlihat pada Tabel 4.

Tabel 4. Hasil uji Duncan untuk penurunan kolesterol

\begin{tabular}{|c|c|c|c|}
\hline \multirow[t]{2}{*}{ Perlakuan } & \multirow[t]{2}{*}{$\mathrm{N}$} & \multicolumn{2}{|c|}{ Subset for alpha $=0.05$} \\
\hline & & 1 & 2 \\
\hline P5 & 3 & -31.3333 & \\
\hline P3 & 3 & & 27.3333 \\
\hline P4 & 3 & & 31.0000 \\
\hline P2 & 3 & & 41.3333 \\
\hline P1 & 3 & & 47.40000 \\
\hline Sig. & & 1.000 & .223 \\
\hline
\end{tabular}

dengan taraf signifikan 95\% menunjukkan bahwa rerata penurunan kadar kolesterol darah tersebut berbeda nyata antara beberapa perlakuan. Perlakuan yang paling berbeda nyata terlihat pada P1, P2, P3, dan P4 yang menunjukkan bahwa P1, P2, dan P3 untuk ekstrak daun alpukat 10\%, 20\%, $40 \%$, dan P4 pemberian obat simvastatin berbeda nyata untuk menurunkan kolesterol darah. Pada (P5) yaitu perlakuan tanpa ekstrak daun alpukat dan obat simvastatin menunjukkan perbedaan yang tidak nyata hal ini dikarenakan bahwa dengan pemberian makanan diet lemak tinggi dan propiltiourasil dapat sangat berperan sebagai menaikkan kadar kolesterol darah pada mencit. Selain itu, juga diduga memiliki kemiripan mekanisme dengan simvastatin karena keduanya mengandung elektron yang bisa didonorkan pada radikal bebas. Dari data uji Duncan pada kadar kolesterol darah menunjukkan bahwa penurunan kadar kolesterol pada darah mencit berbanding terbalik dengan peningkatan konsentrasi ekstrak daun alpukat. Dengan kata lain semakin kecil konsentrasi ekstrak daun alpukat maka semakin besar pula penurunan kadar kolestrol darah. Konsentrasi yang paling efektif dari daun alpukat yang dapat menurunkan kadar kolesterol darah pada mencit adalah perlakuan P1 yaitu dengan pemberian konsentrasi ekstrak daun alpukat $10 \%$.

Hasil yang diperoleh menunjukkan bahwa ekstrak daun alpukat dengan konsentrasi 10\% efektif dalam menurunkan kadar kolesterol darah. Keefektifan ekstrak daun alpukat yang mampu menurunkan kolesterol darah kemungkinan dipengaruhi oleh zat bioaktif yang terkandung dalam ekstrak daun alpukat tersebut. Dimana zat bioaktif yang terkandung dalam ekstrak tersebut lebih banyak mempengaruhi penurunan kolesterol darah pada ekstrak daun alpukat dengan konsentrasi $10 \%$ dibandingkan dengan konsentrasi $20 \%$, dan $40 \%$ dan obat simvastatin. Disini terlihat bahwa dengan konsentrasi terbesar yang digunakan, efeknya lebih kecil dari pada konsentrasi yang kecil. Hal ini sering dijumpai pada aktivitas ekstrak bahan alam yang merupakan campuran multikomponen. Pengaruh lain adalah karena terjadinya perbedaan kelarutan dari konsentrasi 10, 20, dan 40\%, sehingga mempengaruhi kerja dan efek dari ekstrak daun alpukat tersebut.
Peningkatan kadar kolesterol dapat disebabkan oleh tiga hal. Pertama, diet yang terlalu banyak mengandung kolesterol dan lemak sehingga tubuh tidak mampu mengendalikannya. Kedua, ekskresi ke kolon melalui asam empedu terlalu sedikit. Ketiga, apabila produksi kolesterol dalam hati terlalu banyak (Baraas, 1993).

Pemberian ekstrak daun alpukat dengan konsentrasi yang berbeda pada mencit (Mus Musculus) memberikan pengaruh yang cukup berbeda terhadap kadar kolesterol darah mencit. Pemberian ekstrak daun alpukat telah cukup dalam mempengaruhi kadar kolesterol darah, sehingga pemberian variasi konsentrasi sedikit mampu dalam menentukan kadar konsentrasi yang baik untuk menurunkan kadar kolestreol darah pada mencit.

Data hasil kelompok P1 yaitu kelompok dengan perlakuan pemberian ekstrak daun alpukat dengan konsentrasi $10 \%$ terbukti terjadi penurunan terhadap kadar kolesterol darah. Hal ini disebabkan dengan adanya kandungan senyawa alkaloid, flavonoid, tanin, saponin, triterpenoid dan steroid, berdasarkan hasil yang diperoleh dalam penelitian ini maka dapat diketahui bahwa semakin kecil konsentrasi ekstrak yang diberikan pada hewan uji maka semakin besar pula pengaruhnya terhadap penurunan kadar kolesterol darah.

Data hasil kelompok kontrol positif menunjukkan kadar kolesterol darah pada kelompok ini memiliki penurunan yang artinya obat simvastatin dapat berpengaruh dalam menurunkan kolesterol. Data hasil kelompok kontrol negatif diberi diet tinggi berupa kuning telur yang memiliki efek dalam meningkatkan kadar kolesterol dalam darah dan menunjukkan kadar kolesterol darah pada kelompok ini memiliki kenaikan yang artinya makanan diet lemak tinggi dapat berpengaruh besar dalam menaikan kolesterol darah.

Adanya penurunan kadar kolesterol darah setelah diberi ekstrak daun alpukat dengan variasi konsentrasi ditunjukan pada diagram dan grafik di atas. Penurunan kadar kolesterol tertinggi terdapat pada P1 dengan besar konsentrasi 10\%. Perubahan kadar kolestreol dalam darah mempunyai pengaruh yang positif bagi tubuh. Kadar kolesterol yang berlebih akan menyebabkan ateroklerosis yang akan berdampak pada penyakit jantung koroner.

Aterosklerosis merupakan suatu kelainan pada pembuluh darah yang ditandai dengan penebalan lapisan intima dinding pembuluh darah oleh karena terbentuknya fibrous plaque. Komposisi fibrous plaque ini sebagian besar adalah lemak terutama kolesterol. Apabila keadaan ini terus berlangsung akan terjadi penyempitan lumen pembuluh darah, sehingga membatasai aliran darah, merangsang terbentuknya bekuan darah, kemudian aliran darah terganggu (Sekarindah, 1997). 


\section{Kesimpulan}

Ekstrak daun alpukat (Persea americana Mill.) mengandung senyawa metabolit sekunder yaitu alkaloid, flavonoid, saponin, tanin, triterpenoid dan steroid. Konsentrasi ekstrak daun alpukat (Persea americana Mill.) yang relatif paling efektif untuk menurunkan kadar kolesterol dalam darah mencit adalah pada konsentrasi $10 \%(\mathrm{~b} / \mathrm{v})$ dengan $\alpha=0,05$.

\section{Ucapan Terima Kasih}

Ucapan terimakasih penulis sampaikan kepada seluruh laboran laboratorium kimia Fakultas Keguruan dan Ilmu Pendidikan Universitas Tadulako yang telah memberikan bimbingan dan masukan dalam menyelesaikan penelitian ini.

\section{Referensi}

Al-Dosari, M. S. (2011). Hypolipidemic and antioxidant activities of avocado fruit pulp on high cholesterol fed diet in rats. Journal of Pharmacy and Pharmacology, 5(12), 14761483.

Arief, M. I., Novriansyah, R., Budianto, I. T., \& Harmaji, M. B. (2012). Potensi bunga karamunting (melastoma malabathricum l.) terhadap kadar kolesterol total dan trigliserida pada tikus putih jantan hiperlipidemia yang diinduksi propiltiourasil. Jurnal Prestasi, 1(2), 118-126.

Astawan, M. (2008). Khasiat warna-warni makanan. Jakarta: Gramedia Pustaka Utama.

Baraas, F. (1993). Mencegah serangan jantung dengan menekan kolesterol. Jakarta: Gramedia Pustaka Utama.

Cowan, M. M. (1999). Plant products as antimicrobial agents. Journal Clinical Microbiology Reviews, 12(4), 564-582.

Dachriyanus, Katrin, D. O., Oktarina, R., Ernas, O., Suhatri, \& Mukhtar, M. H. (2007). Uji efek $\alpha$-mangostin terhadap kadar kolesterol total, trigliserida, kolesterol hdl, dan kolestrol ldl darah mencit putih jantan serta penentuan lethal dosis 50 (ld50). Jurnal Sains Teknik Farmasi, 12(2), 64-72.

Dharmayudha, A. A. G. O., \& Anthara, M. S. (2013). Identifikasi golongan senyawa kimia dan pengaruh ekstrak etanol buah naga daging putih (hylocereus undatus) terhadap penurunan kadar glukosa darah serta bobot badan tikus putih jantan (rattus novergicus) yang diinduksi aloksan. Jurnal Buletin Veteriner Udayana, 5(1), 31-40.

Faisal. (1993). Mencegah serangan jantung dengan menekan kolesterol. Jakarta: Gramedia Pustaka Utama.

Freeman, M., \& Junge, C. (2005). Kolesterol rendah jantung sehat. Jakarta: BIP.
Harborne, J. B. (1987). Metode fitokimia tumbuhtumbuhan. Bandung: ITB.

Katja, D. G., Suryanto, E., \& Wehantouw, F. (2009). Potensi daun alpukat (persea americana mill) sebagai sumber antioksidan alami. Journal Chemistry Program, 2(1), 58-64.

Kusumawati, I., Djatmiko, W., Rahman, A., Studiawan, H., \& Ekasari., W. (2003). Eksplorasi keanekaragaman dan kandungan kimia tumbuhan obat dihutan tropis gunung arjuno. Jurnal Bahan Alam Indonesia, 2(3), 100-104.

Metwally, M. A. A., El-Gellal, A. M., \& ElSawaisi, S. M. (2009). Effects of silymarin on lipid metabolism in rats. Journal World Applied Sciences, 6(12), 1634-1637.

Murray, R. K., Granner, D. K., \& Rodwell, V. W. (2003). Biokimia Harper. Jakarta: Kedokteran EGC.

Ong, A. K. (2013). Eksplorasi keanekaragaman dan kandungan kimia tumbuhan obat dihutan tropis gunung arjuno. Jurnal Ilmiah Mahasiswa Universitas Surabaya, 2(1), 2-15.

Povey, R., Wulandari, \& Widayanti, D. (1994). How to keep your cholesterol in check. Memantau kadar kolesterol anda. Jakarta: Arcan.

Putri, E. P. K. (2013). Analisis kualitatif zat bioaktif pada ekstrak daun alpukat (persea americana mill.) dan uji praklinis dalam menurunkan kadar glukosa darah pada mencit (mus musculus). Skripsi, Universitas Tadulako, Palu.

Rahayu, T. (2005). Kadar kolesterol darah tikus putih (rattus norvegicus L) setelah pemberian cairan kombucha per-oral. Jurnal Penelitian Sains \& Teknologi, 6(2), 85-100.

Rerkasem, K., Gallagher, P. J., Grimble, R. F., Calder, P. C., \& Shearman, C. P. (2008). Managing hypercholesterolemia and its correlation with carotid plaque morphology in patients undergoing carotid endarterectomy. Journal Vascular Health and Risk Management, $4(6), 1259-1264$.

Rinaldi, B. (2011). Analisis efek air perasan kulit buah rambutan (nephelium lappaceum) terhadap penurunan kadar kolesterol pada darah mencit (mus musculus). Skripsi, Universitas Tadulako, Palu.

Rohyami, Y. (2008). Penentuan kandungan flavonoid dari ekstrak metanol daging buah mahkota dewa (phaleria macrocarpa scheff boerl). Jurnal Logika, 5(1), 1-12.

Sangi, M. S., Momuat, L. I., \& Kumaunang, M. (2012). Uji toksisitas dan skrining fitokimia tepung gabah pelepah aren (arenga pinnata). Jurnal Ilmiah Sains, 12(2), 128-134.

Sekarindah, T. (1997). Peran diet pada pencegahan aterosklerosis Indonesia: Majalah Kedokteran. 
Sirait, M. (2007). Penurunan fitokimia dalam farmasi. Bandung: ITB.

Uneputty, J. P., Yamlean, P. V. Y., \& Kojong, N. S. (2013). Potensi infusa daun sirsak (annona muricata 1.) terhadap kadar kolesterol darah tikus putih jantan (rattus novergicus). Jurnal Ilmiah Farmasi, 2(2), 56-60.
Widiyati, E. (2006). Penentuan adanya senyawa triterpenoid dan uji aktivitas biologis pada beberapa spesies tanaman obat tradisional masyarakat pedesaan bengkulu. Jurnal Gradien, 2(1), 116-122.

Yuniarti, T. (2008). Ensiklopedia tanaman obat tradisional. Jogyakarta: Media Pressindo. 